\title{
Prevalence and Risk Factors for Transmission and Genotype of HCV in Iraqi Patients
}

\author{
Khalid Abdulla Al-Khazraji ${ }^{1}$, Wissam Khudhair Abbas $^{2}$ \& Safiya Khalid Abdullah ${ }^{1}$ \\ ${ }^{1}$ Professor of Gastroenterology, College of Medicine, Baghdad University, Iraq \\ ${ }^{2}$ Al-Mustansiriya University, College of Medicine, Iraq \\ Correspondence: Khalid Abdulla Al-Khazraji, MBCHB, MD, CAMB, FRCP, FACP, Professor of \\ Gastroenterology, College of Medicine, Baghdad University, Iraq.
}

Received: September 2, 2019 Accepted: October 8, 2019 Online Published: October 24, 2019

doi:10.5539/gjhs.v11n12p185 URL: https://doi.org/10.5539/gjhs.v11n12p185

\begin{abstract}
Background: Hepatitis $\mathrm{C}$ virus (HCV) infection is a serious public health problem in the world, and about 170 million patients are chronically infected with HCV. Worldwide; different epidemiologic patterns of HCV infection have been identified.

Aim of the Study: By this study, we try to know the prevalence and risk factors for HCV transmission in Iraqi patients and genotype distribution of the disease.

Patients and Methods: In a cross sectional study of 355898 persons, 232645 males \& 123253 females; had been enrolled for the study in Baghdad teaching hospital, Iraqi blood bank, Al-Yarmouk teaching hospital, Al-Nu'man teaching Hospital and Al-Basrah teaching hospital from February 2017 to February 2019. Positive patients for hepatitis $\mathrm{C}$ antibody were further studied for way of transmission and viral load and genotype. History had been taken about the possible risk factor for HCV transmission which included (15) risk factors.
\end{abstract}

Results: A total of 355898 persons, 232645 males \& 123253 females their Mean age at diagnosis was $47.3( \pm 15.6)$ years, Ranged (19-78) years. The mean body mass index (BMI) of the study sample was $22.9( \pm 3) \mathrm{kg} / \mathrm{m} 2$, studied all screen for hepatitis $\mathrm{C}$ antibody 1155 discovered to be positive 650 were males and 505 were females, further study done for viral load in 746 patients and genotype in 633 patients: $356(48 \%)$ with high viral load, 390 (52\%)with low viral load and $345(52.8 \%)$ with genotype V and 301 (46.2\%) with genotype IV, while genotype II was $2(0.3 \%)$ and III $7(0.5 \%)$, The most common possible ways of transmission of the disease by history in this study was blood transfusion $53 \%$, dental procedure $42 \%$, hemodialysis $36 \%$, caesarean section $34.5 \%$, while injured male during shaving $33 \%$, patient who have surgical operation $24 \%$, Tattooing in $8 \%$, cupping in $6.6 \%$, IV injection in $4 \%$ heterosexual seen in $2 \%$, renal transplant in $2 \%$, and only $1 \%$ in needle stick injury. while the more frequent genotype is 1 then 4 . Hemodialysis and improper use of IV medication had been found to be more significant in $\mathrm{HCV}$ male patients. The relation between possible risk factor for transmission of $\mathrm{HCV}$ and residence, viral load were not significant.

Conclusion: The most common probable risk factors as single risk factor for the male was blood transfusion, and for female was caesarean section. While for two risk factors for male were Blood transfusion and Hemodialysis and for female were Caesarean section \& Dental procedure and for both gender were hemodialysis \& dental procedure.

While for three risk factors for both gender were surgery, barbers, and dental procedure. In our study we had found the prevalence of $\mathrm{HCV}$ in our Iraqi big sample was relatively low. The most common genotype was genotype I then genotype IV with rarity of genotype III 0 and genotype II.

Keywords: hepatitis C, genotype, prevalence, transmission

\section{Introduction}

$\mathrm{HCV}$ present in all continents, and about 170 million patients are chronically infected with HCV. In industrialized countries, the incidence of HCV infection has decreased considerably due to blood screening and measures that prevent HCV infections in intravenous drug users (Goldman \& Schafer, 2015; Moradpour \& Penin, 2013). 
However, according to the Centers for Disease Control and Prevention about 17,000 new cases of acute HCV still occur annually in the United States. In France, about 2500 new infections occur yearly. In developing areas of the world; $\mathrm{HCV}$ incidence and prevalence are higher in which the main route for HCV infection is unsafe medical or surgical procedures, only about $50 \%$ of blood products are screened for Anti-HCV antibodies in these countries, and about $40 \%$ of all injections are assumed to be given with reused equipment (Moradpour \& Penin, 2013; Feldman, Friedman, \& Brandt, 2015).

Worldwide; three different epidemiologic patterns of HCV infection have been identified. They are (1) previous exposure through health care with peak prevalence in older patients; (2) exposure due to IV drug using; the major risk factor since about 1960 . When data first became available with peak prevalence among middle-aged persons; and (3) ongoing high levels of HCV infection in areas in which high rates infection occur in all age groups (Cheifetz, Brown, Curry, \& Moss, 2011).

All over the world; Subtypes $\{1 \mathrm{a}\}$ and $\{1 \mathrm{~b}\}$ predominate. In the United States; the most common genotypes are $\{1 \mathrm{a}\}$ and $\{1 \mathrm{~b}\}$ about $75 \%,\{2 \mathrm{a}\}$ and $\{2 \mathrm{~b}\}$ about $15 \%$, and $\{3 \mathrm{a}\}$ about $7 \%$. Genotype $\{3 a\}$ is more prevalent in Western Europe where it accounts approximately $35 \%$ of cases, specifically among intravenous drug users.

Genotype $\{4\}$ is highly prevalent in Middle East and Africa. Its incidence and prevalence had been found to be increase in IV drug users in industrialized countries. Genotype $\{5\}$ is rare outside South Africa, and genotype $\{6\}$ is rare outside Southeast Asia, Genotype VII has been reported in Canada from central African immigrants (Goldman \& Schafer, 2015; Cheifetz et al., 2011).

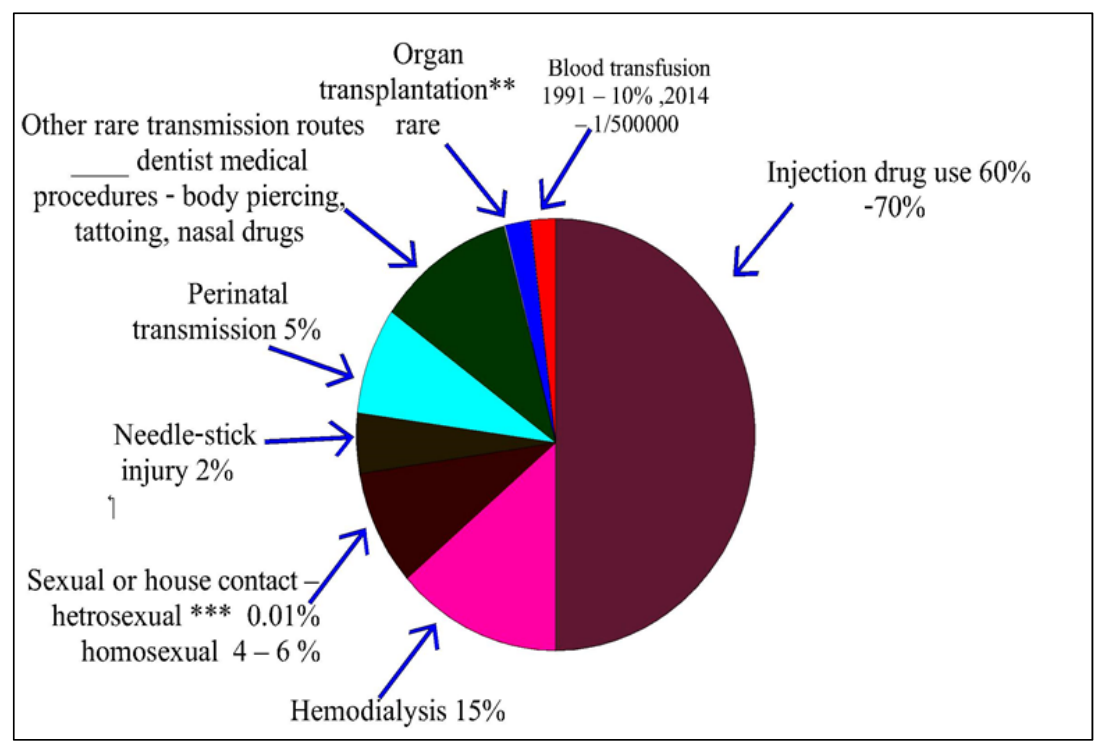

Figure 1. Common ways of transmission of hepatitis $\mathrm{C}$

\section{Patients and Methods}

In this cross sectional retrospective study; from February 2017 to February 2019 we studied all people who attend four big hospitals, three of them in Baghdad: (Baghdad medical city, Al- Yarmouk teaching hospital, Al-Nu'man teaching Hospital) and one hospital in Basrah (Al-Basrah teaching hospital).

Those people attended hospitals before surgery or pregnant or marriage, or seeking for medical treatment for advice for their complaint, all were screen for hepatitis $\mathrm{C}$, any positive result was recorded in the lab file or sent by the patient to GIT and medical consultation department where it also recorded in specific file. So all people had been documented in one or these two places, their total number were 165273 and we studied all looking healthy people and who attending main Baghdad blood bank for donation who were screen for hepatitis $\mathrm{C}$, the total number was 190625 persons, so by collection of both samples from the hospital and blood bank the total number was 355898,232645 were males, and 123253 were females, total persons who were positive for hepatitis C were 1155 , males were $650(56 \%)$ and females $505(44 \%)$.

Further evaluation of positive patients were done looking for their viral load by PCR and genotype for hepatitis C, both of these lab tests were done in private lab because they were not available in those hospitals, positive persons 
were recorded in special file and signed for that in order not to donate again and we took documentation form these files.

The questionnaire in this study for multiple risk factors for HCV transmission included;

1). History of blood transfusion

2). Hemodialysis

3). Caesarean section for female.

4). Injured male during shaving by barber.

5). Patients who had dental procedure.

6). Surgical operation.

7). Tattooing.

8). Cupping.

9). Improper use of IV medication (by intravenous route without medical prescription).

10). Body piercing.

11). Sexual or household.

12). Organ transplant.

13). Needle stick.

14). Perinatal.

15). Drug abuse (intravenous drug abuse IVDU).

We did evaluate the prevalence of the genotype and the viral load and it's relationship to the root of transmission so we consider:

1). High viral load (>800000 IU/ml).

2). Low viral load (<800000 IU/ml). (Koziel, 1997; Franciscus et al., 2011; Carey, 2003)

\subsection{Statistical Analysis}

Each patient assigned a serial identification number. The data were analyzed using the Statistical Package for Social Sciences (SPSS) version 20. The categorical data presented as frequency and percentage tables.

The continuous data were represented by mean, standard deviation and range. The Chi-square was used to assess the association between categorical variables. $\mathrm{P}$ - Value less than 0.05 was used as the alpha level of significance. Finally all findings and results were presented in tables and figures with an explanatory paragraphs for each table and figure.

\section{Results}

Patients who had been confirmed to have hepatitis $C$ positive (1155) patients of these, (505) patients were female and (650) patients were male. Their ages were ranging from (19) to (78) years with mean age at presentation $=48.1$ (standard deviation $[\mathrm{SD}] \pm 15.8)$ years. Also their mean age at diagnosis $=47.3(\mathrm{SD} \pm 15.6)$ years.

BMI normal value are:

Underweight $=<18.5$

Normal weight $=18.5-24.9$

Overweight $=25-29.9$

Obesity $=$ BMI of 30 or greater

Their body mass index (BMI) was divided into:

1) Below normal weight; $<18.5 \mathrm{~kg} / \mathrm{m}^{2}$ were $9 \%$

2) Normal weight; $18.5-25 \mathrm{~kg} / \mathrm{m}^{2}$ were $62 \%$

3) Over weight; $\geq 25 \mathrm{~kg} / \mathrm{m} 2$ were $29 \%$. (WHO, 2014)

The mean body mass index $=22.9(\mathrm{SD} \pm 3) \mathrm{kg} / \mathrm{m}^{2}$, Their BMI range $(17-29) \mathrm{kg} / \mathrm{m}^{2}$. 
Table 1. Socio-demographic characteristics of cases with HCV infection

\begin{tabular}{lll}
\hline Variables & Number & \% \\
\hline Gender & 650 & 56 \\
Male & 505 & 44 \\
Female & & \\
\hline Residence & 914 & \\
Urban & 241 & \\
Rural & & 9 \\
\hline Body mass index categories & 96 & 62 \\
$<18.5 \mathrm{Kg} / \mathrm{m}^{2}$ & 684 & 29 \\
$18.5-25 \mathrm{Kg} / \mathrm{m}^{2}$ & 375 & \\
$>=25 \mathrm{Kg} / \mathrm{m}^{2}$ & & 10 \\
\hline No. of partners & 117 & 89.9 \\
Single & 1038 & 52 \\
Married & & 20 \\
\hline Occupation & 490 & 9 \\
Housewife & 309 & 4 \\
Constructor & 101 & 4 \\
Retired & 18 & 1 \\
Student & 17 & $\mathbf{1 0 0 \%}$ \\
Teacher & 60 & \\
Healthcare worker & 140 & $\mathbf{1 1 5 5}$ \\
Others & & \\
\hline Total & & \\
\hline
\end{tabular}

Mean age at presentation $=48.1$ (standard deviation $[\mathrm{SD}] \pm 15.8)$ years.

Mean Age at diagnosis $=47.3( \pm 15.6)$ years, Range $(19-78)$ years.

Body mass index $=22.9( \pm 3) \mathrm{kg} / \mathrm{m}^{2}$, Range $(17-29) \mathrm{kg} / \mathrm{m}^{2}$.

\subsection{Prevalence of HCV in Studied Sample}

Prevalence of HCV in studied sample

\begin{tabular}{llll}
\hline Point prevalence & Female & Male & All \\
\hline Per 100\% & $0.41 \%$ & $0.28 \%$ & $0.32 \%$ \\
\hline Per 100,000 (95\%CI) & 409.7 & 279.4 & 324.5 \\
& $(406.2-413.3)$ & $(277.3-281.5)$ & $(322.7-326.4)$ \\
\hline
\end{tabular}

95\%CI: 95 percent confidence interval. 


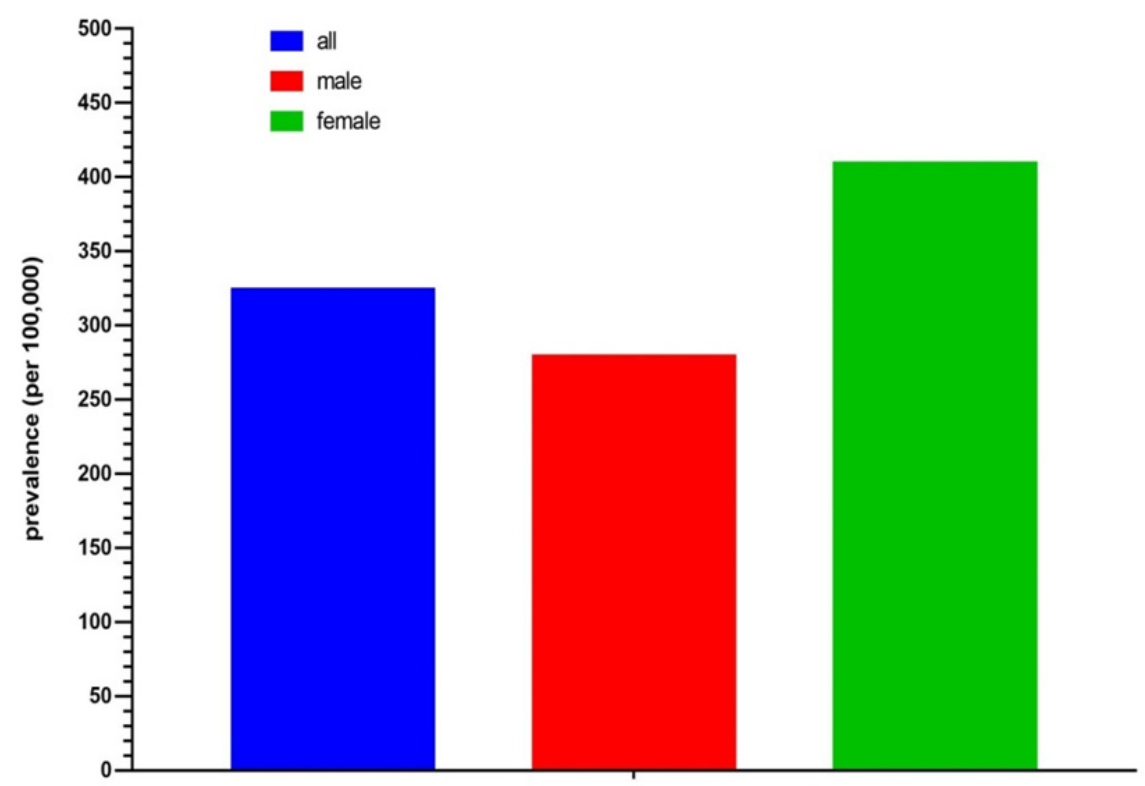

Figure 2. Prevalence of $\mathrm{HCV}$

\subsection{HCV Characters Among the Studied Cases}

From the (1155) patients, viral load was done in (746) patients which range $(5200-10500000 \mathrm{IU} / \mathrm{ml})$ and their Median is $688000 \mathrm{IU} / \mathrm{m}$. (356 patients had high viral load (>800000 IU/ml) to comprise (48\%), while (390) patients had low viral load $(<800000 \mathrm{IU} / \mathrm{ml})$ and comprise $(52 \%)$.

Also from the (746) patients, only (653) patients had done their genotype.

Genotype I is found in (345) patients to comprise (52.8\%) genotype Ia 152 and Ib 193, and genotype 4 is found in (301) patients to comprise (46.2\%), while genotype III is found only in 7 case to comprise $(0.5 \%)$ and genotype II in 2 cases $0.3 \%$.As shown in Table 2 .

Table 2. Characteristics of HCV among the studied cases

\begin{tabular}{lll}
\hline Variables & Number & \% \\
\hline Viral load & & \\
High viral load $(>800000 \mathrm{IU} / \mathrm{mL})$ & 356 & 48 \\
Low viral load $(<800000 \mathrm{IU} / \mathrm{mL})$ & 390 & 52 \\
Total & 746 & 100 \\
Median (Range) IU / mL & $688000(5200-10500000)$ & \\
\hline Genotype & & \\
I & 345 & 52.8 \\
Ia & 152 & - \\
Ib & 193 & - \\
IV & 301 & 46.2 \\
III & 7 & 0.5 \\
II & 2 & 0.3 \\
V & 0 & 0 \\
VI & 0 & 0 \\
\hline
\end{tabular}




\subsection{Number and Percentage of Cases, According to Possible Risk Factors for HCV Transmission}

Patients with blood transfusion history were (536) to comprise (53\%), those with dental procedures surgery are (425) to comprise (42\%). Those who underwent hemodialysis whom were negative for hepatitis $\mathrm{C}$ before starting hemodialysis and then got positive result hemodialysis their number is (364) to comprise (36\%).

Female sustained Caesarean section (C.S) were (193) from total number of 505 of female to comprise (34.5\%), while injured male patients during shaving by barbers are (216) from total 650 to comprise (33\%).

Patients who have history of surgical operation were 243 to comprise (24\%). while only (84) patients had done tattooing comprising (8\%). patients with history of cupping are (67) to comprise $(6 \%)$, and number of patients who took intravenous injections by their own without medical prescription (improper use of IV medication) is (45) to comprise (4\%). and (43) patients had done body piercing comprising (4\%).

21 patients had Sexual history (heterosexual) i.e.; $2 \%$ of total. Also 22 patients had organ(Renal) transplantation who were negative before that, and comprise (2\%), while only 11 patient had needle stick injury(nurse) to comprise (1\%), and no case with history of perinatal,intravenous drug abuse(IVDU) or idiopathic.

These data are presenting in Table 3:

Table 3. Number and percentage of cases, according to possible risk factors for HCV transmission

\begin{tabular}{lll}
\hline Risk factor & No (1155) & \% \\
\hline History of blood transfusion & 536 & 53 \\
Dental procedure & 425 & 42 \\
Hemodialysis & 364 & 36 \\
Caesarean section (total=55) & 191 & 34.5 \\
Injured males by barbers (total=45) & 33 \\
Surgical operation & 216 & 24 \\
Tattooing & 243 & 8 \\
Cupping & 84 & 6 \\
Improper use of IV medication & 67 & 4 \\
Body piercing & 48 & 4 \\
Sexual or household & 46 & 2 \\
Organ transplant & 21 & 2 \\
Needle stick & 22 & 1 \\
Perinatal & 11 & 0 \\
Drug abuse & 0 & 0 \\
Idiopathic & 0 & 0
\end{tabular}

*no. of females with history of caesarian section per total 505 females.

**no. of males with history of injury by barbers per total 650 males. 


\subsection{Average Age at Diagnosis, According to Patients 'Gender'}

Table 4. Average age at diagnosis, according to patients' gender

\begin{tabular}{llll}
\hline \multirow{2}{*}{ Age (year) } & Male & Female & P value \\
& $\mathbf{N}=\mathbf{6 5 0}$ & $\mathbf{N}=\mathbf{5 0 5}$ & \\
\hline Mean $\pm \mathbf{S D}$ & Mean \pm SD & 0.119 \\
\hline
\end{tabular}

Student's t-test, $\mathrm{SD}=$ Standard deviation.

\subsection{Average Age at Diagnosis, According to Possible Risk Factor for Transmission}

By this we found that mean age at diagnosis for patients with history of body piercing and history of organ transplantation was younger than other risk factors which their mean age at diagnosis was at middle age. As shown in Table 5:

Table 5. Average age at diagnosis, according to possible risk factors of transmission

\begin{tabular}{ll}
\hline \multirow{2}{*}{ Risk factor } & Age at diagnosis \\
\cline { 2 - 2 } & Mean \pm SD (Range) \\
\hline Improper use of IV medication & $60.75 \pm 12.74(44-75)$ \\
History of blood transfusion & $50.87 \pm 15.13(19-75)$ \\
Hemodialysis & $48.58 \pm 14.98(20-75)$ \\
Sexual or household & $52.5 \pm 17.68(40-65)$ \\
Surgical operation & $55.12 \pm 14.52(27-78)$ \\
Body piercing & $25.75 \pm 4.57(20-31)$ \\
Needle stick & 41 \\
Organ transplant & $27.5 \pm 10.6(20-35)$ \\
Cupping & $54.7 \pm 9(44-64)$ \\
Tattooing & $48.1 \pm 16.4(31-75)$ \\
Female C/S & $42 \pm 14.6(22-75)$ \\
Shaving among males & $48.6 \pm 11.8(23-62)$ \\
Dental procedure & $48.9 \pm 15(20-75)$ \\
\hline
\end{tabular}

3.6 Relation Between Number of Possible Risk Factors for HCV Transmission and Number of Patients for That Number

By this relation we find that there are (398) patients have history of single risk factor of transmission, (380) patients have history of two risk factors of transmission, (248) patients have history of three risk factors of transmission while (124) patients have history of four risk factors of transmission.

For the single risk factor, (178) patients have history of blood transfusion due to anemia, peptic ulcer, menorrhagia, pregnancy and hemorrhoids .Also we have (56) patients for dental procedure and 52 for caesarian section(c/s), (38) for surgical operation and injured male by barbers during shaving was 35 while (13) patient for each hemodialysis, body piercing was 14 and tattooing was 13 as shown below in Table 6 . 
Table 6. Number of possible risk factors of transmission and patients Number

\begin{tabular}{|c|c|}
\hline Risk factors & Number of patients \\
\hline Single risk factor & $\mathrm{N}=398$ \\
\hline Hemodialysis & 13 \\
\hline Piercing & 14 \\
\hline Tattooing & 18 \\
\hline barbers & 35 \\
\hline Surgery & 37 \\
\hline Dental procedure & 56 \\
\hline Caesarean section & 252 \\
\hline Blood transfusion & 178 \\
\hline Two risk factors & $\mathrm{N}=380$ \\
\hline Hemodialysis, Cupping & 17 \\
\hline barbers, Dental procedure & 16 \\
\hline Blood transfusion, Cupping & 17 \\
\hline Cupping, Dental procedure & 18 \\
\hline Piercing, Dental procedure & 19 \\
\hline Cupping, Tattooing & 14 \\
\hline Hemodialysis, Transplant & 13 \\
\hline Blood transfusion, Dental procedure & 15 \\
\hline Hemodialysis, Caesarean section & 25 \\
\hline Blood transfusion, Caesarean section & 23 \\
\hline Surgery, Dental procedure & 24 \\
\hline Blood transfusion, Surgery & 33 \\
\hline Hemodialysis, Dental procedure & 41 \\
\hline Caesarean section, Dental procedure & 47 \\
\hline Blood transfusion, Hemodialysis & 58 \\
\hline Three risk factors & $\mathrm{N}=248$ \\
\hline Hemodialysis, Surgery, barbers & 16 \\
\hline Blood transfusion, Hemodialysis, Caesarean section & 17 \\
\hline Blood transfusion, Hemodialysis, Surgery & 15 \\
\hline Hemodialysis, Sex household, Dental procedure & 12 \\
\hline Blood transfusion, Hemodialysis, barbers & 13 \\
\hline Blood transfusion, Hemodialysis, Caesarean section & 11 \\
\hline Blood transfusion, Hemodialysis, Transplant & 14 \\
\hline Blood transfusion, Surgery, barbers & 13 \\
\hline Blood transfusion, Caesarean section, Dental procedure & 12 \\
\hline Cupping, Caesarean section, Dental procedure & 13 \\
\hline Blood transfusion, Surgery, Dental procedure & 13 \\
\hline Sex household, barbers, Dental procedure & 12 \\
\hline Blood transfusion, Hemodialysis, Surgery & 22 \\
\hline Blood transfusion, Hemodialysis, Dental procedure & 31 \\
\hline
\end{tabular}


Surgery, barbers, Dental procedure

32

Four risk factors

Improper use of IV medication, Hemodialysis, Surgery,

16

Dentists

Blood transfusion, Hemodialysis, Needle stick, Tattooing

17

Blood transfusion, Hemodialysis, Caesarean section, Dentists

Hemodialysis, Tattooing, barbers, Dentists

12

Blood transfusion, Surgery, Tattooing, Caesarean section

\subsection{Relation of Cases' Gender With Possible Risk Factors of Transmission}

Table 7. Relation of cases' gender with possible risk factors of transmission

\begin{tabular}{llllll}
\hline \multirow{2}{*}{ Risk factor } & \multicolumn{2}{l}{ Gender } & & \multicolumn{2}{c}{ p-value } \\
\cline { 2 - 5 } & $\begin{array}{l}\text { Male } \\
\text { No. }(\mathbf{N}=\mathbf{6 5 0})\end{array}$ & $\mathbf{\%}$ & $\mathbf{N o}$. (N=505) & $\mathbf{\%}$ & \\
\hline History of blood transfusion & 232 & 51.1 & 300 & 54.5 & 0.732 \\
Dental procedure & 194 & 42.2 & 23 & 41.8 & 0.968 \\
Hemodialysis & 211 & 46.7 & 157 & 27.3 & 0.044 \\
Surgical operation & 132 & $28.9 \%$ & 119 & $20.0 \%$ & 0.3 \\
Tattooing & 24 & $4.4 \%$ & 67 & $10.9 \%$ & 0.236 \\
Cupping & 41 & $8.9 \%$ & 23 & $3.6 \%$ & 0.271 \\
Improper use of IV medication & 41 & $8.9 \%$ & 0 & $0 \%$ & 0.024 \\
Body piercing & 0 & $0 \%$ & 40 & $7.3 \%$ & 0.065 \\
Sexual or household & 22 & $4.4 \%$ & 0 & $0 \%$ & 0.114 \\
Organ transplant & 21 & $4.4 \%$ & 0 & $0 \%$ & 0.114 \\
Needle stick & 0 & 0.0 & 19 & 1.8 & 0.363 \\
\hline
\end{tabular}

Chi-square test, ${ }^{*}$ Significant at 0.05 level.

\subsection{Relation of Cases' Residence With Possible Risk Factors of Transmission}

According to the residence wither urban or rural areas,there are (90) patients from urban area and (10) patients from rural area .The risk factors with high percentages in urban area are dental procedure, hemodialysis, surgical operation, cupping, sexual contact, organ transplantation and needle stick injury .

While in rural area the risk factors of high percentages are blood transfusion, tattooing, improper use of IV medication and body piercing.

Significant p-value have not been found as shown in Table 8 . 
Table 8. Relation of cases' residence with possible risk factors of transmission

\begin{tabular}{|c|c|c|c|c|c|}
\hline \multirow{3}{*}{ Risk factor } & \multicolumn{4}{|l|}{ Residence } & \multirow{3}{*}{ p-value } \\
\hline & \multicolumn{2}{|l|}{ Urban } & \multicolumn{2}{|l|}{ Rural } & \\
\hline & No. $(\mathrm{N}=1029)$ & $\%$ & No. $(\mathrm{N}=126)$ & $\%$ & \\
\hline History of blood transfusion & 380 & 42 & 63 & 50 & 0.640 \\
\hline Dental procedure & 340 & 33 & 40 & 31.7 & 0.892 \\
\hline Hemodialysis & 204 & $24 \%$ & 28 & $22 \%$ & 0.267 \\
\hline Surgical operation & 122 & $12 \%$ & 29 & $22 \%$ & 0.755 \\
\hline Tattooing & 70 & $7 \%$ & 11 & $0.8 \%$ & 0.806 \\
\hline Cupping & 63 & $6 \%$ & 0 & $0 \%$ & 0.4 \\
\hline Improper use of IV medication & 30 & $3 \%$ & 11 & $0.8 \%$ & 0.306 \\
\hline Body piercing & 30 & $2 \%$ & 9 & $0.7 \%$ & 0.306 \\
\hline Sexual or household & 22 & $2 \%$ & 0 & $0 \%$ & 0.634 \\
\hline Organ transplant & 21 & $2 \%$ & 0 & $0 \%$ & 0.634 \\
\hline Needle stick & 19 & 1.2 & 0 & 0.0 & 0.738 \\
\hline
\end{tabular}

Chi-square test.

\subsection{Relation of Viral Load Categories With Possible Risk Factor for Transmission}

From the total (1155) patients; only (746) patients had done their viral load. From the (350) patients; (390) patients with low viral load $(<800000 \mathrm{IU} / \mathrm{ml})$, and (350) patients with High viral load $(>800000 \mathrm{IU} / \mathrm{ml})$.

For patients who have history of tattooing, body piercing, sexual contact, organ transplantation and needle stick injury have been found to have high percentage of low viral load compared with other patients who have same risk factor but with high viral load.

For patients who have history of blood transfusion, hemodialysis, dental procedure, surgical operation, cupping and improper use of IV medication have been found to have high percentage of high viral load compared with other patients who have same risk factor but with low viral load .

P-value regarding this relation was not significant. As shown in Table 9.

Table 9. Relation of viral load categories with possible risk factor for transmission

\begin{tabular}{llllll}
\hline \multirow{2}{*}{ Risk factor } & Low viral load & \multicolumn{2}{c}{ High viral load } & p-value \\
\cline { 2 - 5 } & No. (N=390) & \% & No. (N=356) & \% & 0.469 \\
\hline History of blood transfusion & 182 & 46.0 & 181 & 50.0 & 0.263 \\
Dental procedure & 148 & 37.0 & 175 & 49.0 & 0.912 \\
Hemodialysis & 143 & $36 \%$ & 132 & $37 \%$ & 0.278 \\
Surgical operation & 72 & $18 \%$ & 98 & $25 \%$ & 0.735 \\
Tattooing & 28 & $7 \%$ & 22 & $6 \%$ & 0.358 \\
Cupping & 29 & $7.4 \%$ & 4 & $2.5 \%$ & 0.493 \\
Improper use of IV medication & 17 & $4.3 \%$ & 24 & $8 \%$ & 0.13 \\
Body piercing & 0 & $0 \%$ & 28 & 0.174 \\
Sexual or household & 22 & $5.6 \%$ & 0 & $0 \%$ & 0.174 \\
Needle stick & 21 & $5 \%$ & 0 & $0 \%$ & 0.174 \\
\hline
\end{tabular}

Chi-square test. 


\section{Discussion}

In our study we had found the prevalence of HCV in our Iraqi big sample was $0.41 \%$ in female, $0.28 \%$ in male and $0.32 \%$ in all, and most common genotype was genotype I $52.8 \%$ then genotype IV $46.2 \%$ with rarity of genotype III $0.5 \%$ and genotype II $0.2 \%$, while the most common occupation for HCV patients is housewife (52\%) and constructor (20\%) which resemble other study done in Egypt at 2014 by Adinolfi et al. (2001).

while health care worker (nurse) comprise (1\%) only. while in the world the occupation which consider a risk factor for HCV acquisition is health care worker where significant prevalence had been found in USA, North Africa, Middle East and South Asia with low prevalence in Europe and no increase prevalence in Japan by study done by Claudia Westermann et al. at 2015 (Westermann et al., 2015).

By our study;the more frequent genotype is 1 then 4.while the genotype 4 is the more frequent in Arabian peninsula region (Saudi Arabia, Yemen, Oman,Bahrain, Qatar, UAE, Kuwait), Sham region (Iraq,Syria, Lebanon, Gaza Strip except Jordan), also in Egypt,Sudan and Libya. While genotype 1 is the more frequent in Jordan and Morocco by study done at 2012 by Mohamed A. Daw et al which mention the more frequent genotype in Arabian world (Daw \& Dau, 2012).

While in a study done by Farahnaz Fallahian et al at 2011; the genotype 1 is the more frequent in Iraq, Bahrain, Jordan, Iran and Turkey.

While genotype 4 was more frequent in Saudi Arabia, Syria, Lebanon, Egypt and Sudan, while genotype 3 was the more in Pakistan.

In Europe, the more prevalent genotype is 1 followed by 3 and 2 (European Association for Study of Liver, 2014). While In the United States; genotype 1 is the more prevalent of HCV infections followed by genotype 2 then 3 while genotype 4, 5, or 6 is the less frequent types (Blatt et al., 2000).

In retrospective study had done by Ekram ABD EL-WAHAB et al in Egypt at 2014 for factors associated with HCV transmission (El-Wahab, Mikheal, Sidkey, \& Shatat, 2014), the results were as follow(percentages of patients reported history of risk factor for transmission); Barbers(sharing manicure set) $72.7 \%$, Parenteral treatment range from once time $14.4 \%$ to more than once $72.2 \%$, Body piercing $52.8 \%$ while blood transfusion $51 \%$, Injection anti bilharzial drug $32.3 \%$, Tattooing $30.8 \%$ while cupping $28.3 \%$, Surgical operation range from minor $16.9 \%$ to major $30.1 \%$.

By comparism these results to our study; there are somewhat similarity with blood transfusion, dentists, surgical operation and needle stick injury. While tattooing, cupping, body piercing, drug abuse and barbers are higher than our percentages results.

By study done at 2005 in Turkey by Beytullah Yildirim et al; the main risk factors for HCV infection in Turkish community are surgical operation, multipartner sex, frequent dental therapy, dental extraction and blood transfusion (Yildirim et al., 2005), which favour our study that blood transfusion, dentists and surgical operation are from the main routes of HCV transmission (Yildirim et al., 2005).

In the developed world (United States, Russia and China); the primary risk factor for HCV transmission is intravenous drug use (Nelson et al., 2011).

In the united states the percentages of risk factors for $\mathrm{HCV}$ transmission are : Injection drug use $60 \%$, sexual contact 15\%, blood transfusion (before screening) $10 \%$, unknown $10 \%$ and other (health care work, hemodialysis, Perinatal) 5\% (Nelson et al., 2011; Xia, Luo, Bai, \& Yu, 2008).

As we notice, there are different percentages for risk factor for HCV transmission in comparism between our study and other studies in different regions in the world and this probably due to different in social, cultural, behavioral and environmental factors.

By our study; there is relation between male gender and infection with HCV by hemodialysis and this similar to other studies had done in united states (Kalautar-Zadeh et al., 2007; Charles et al., 2005) and Europe (Italy) (by Natov et al., 2005) while there was no relation between gender and infection with HCV by hemodialysis by study done in Iraq at 2010 (Al-Rubiaei, 2010).

By our study there are no relations between risk factor for HCV transmission and patients residence, while by other studies done in Egypt (by Mohamed et al., 1996; Guerra et al., 2012) and Australia (Roberts \& Algert, 2000) had shown that HCV infection increase in rural areas (Pallás et al., 1999).

\section{Conclusions}

By our study we found there are multiple risk factor for infection by HCV in Iraqi patients, and the most probable 
common risk factors are hemodialysis, dental extraction, surgical operation, blood transfusion, caesarean section,injured male by barbers and. Most probable risk factor for patients with HCV infection who had history of single route of transmission is blood transfusion. While the most common two result was dental procedure and caesarean section.

Also there are significant transmission of $\mathrm{HCV}$ by hemodialysis and improper use of IV medication with male patient.

There are difference in prevalence of risk factors for HCV transmission in HCV Iraqi patients and other regions in the world which belong to differences in social, cultural, behavioral and environmental factors.

The incidence of genotype I is $52 \%$ is more than genotype IV is 465 in our study. While genotype III was $0.5 \%$ and II only $0.3 \%$.

-from total 355899 persons; 1155 were positive for $\operatorname{HCV}(0.32)$, male $=232645$ and 650 of them were positive $(0.28)$ and female $=123253$ and 505 of them were positive $(0.41)$.

\section{Competing Interests Statement}

The authors declare that there are no competing or potential conflicts of interest.

\section{References}

Adinolfi, L. E., Gambardella, M., Andreana, A., Tripodi, M. F., Utili, R., \& Ruggiero, G. (2001). Steatosis accelerates the progression of liver damage of chronic hepatitis $\mathrm{C}$ patients and correlates with specific $\mathrm{HCV}$ genotype and visceral obesity. Hepatology, 33(6), 1358-1364. https://doi.org/10.1053/jhep.2001.24432

Al-Rubiaei, H. M. (2010). Seroconversion Rate of Hepatitis C Virus Infection in Haemodialysis Patients in AL-Kadhymia Teaching Hospital. 2010

Blatt, L. M., Mutchnick, M. G., Tong, M. J., Klion, F. M., Lebovics, E., Freilich, B., ... \& Conrad, A. (2000). Assessment of hepatitis C virus RNA and genotype from 6807 patients with chronic hepatitis $\mathrm{C}$ in the United States. Journal of viral hepatitis, 7(3), 196-202. https://doi.org/10.1046/j.1365-2893.2000.00221.x

Carey, W. (2003). Tests and screening strategies for the diagnosis of hepatitis C. Cleveland Clinic journal of medicine, 70(4), S7. https://doi.org/10.3949/ccjm.70.Suppl_4.S7

Cheifetz, A. S., Brown, A., Curry, M., \& Moss, A. C. (2011). Oxford American handbook of gastroenterology and hepatology (p. 183). Oxford University Press.

Daw, M. A., \& Dau, A. A. (2012). Hepatitis C virus in Arab world: a state of concern. The Scientific World Journal, 2012. https://doi.org/10.1100/2012/719494

El-Wahab, E. W. A., Mikheal, A., Sidkey, F., \& Shatat, H. Z. (2014). Factors associated with hepatitis C infection among chronic HCV Egyptian patients. Iranian journal of public health, 43(11), 1510.

European Association for Study of Liver. (2014). EASL Clinical Practice Guidelines: management of hepatitis C virus infection. Journal of hepatology, 60(2), 392. https://doi.org/10.1016/j.jhep.2011.02.023

Feldman, M., Friedman, L. S., \& Brandt, L. J. (Eds.). (2015). Sleisenger and Fordtran's Gastrointestinal and Liver Disease E-Book (10th ed., Vol. 1, Chapter 80, p. 1336). Elsevier Health Sciences.

Franciscus, A., Lusk, H., Hoex, L., \& Design, B. K. (2011). Hepatitis C Support Project. Guía Para Comprender la Hepatitis B. Versión, 4.

Goldman, L., \& Schafer, A. I. (2015). Goldman-Cecil Medicine E-Book. Elsevier Health Sciences.

Guerra, J., Garenne, M., Mohamed, M. K., \& Fontanet, A. (2012). HCV burden of infection in Egypt: result from a $\begin{array}{lllll}\text { nationwide survey. Journal of viral hepatitis, } & 19(8), & 566-567 .\end{array}$ https://doi.org/10.1111/j.1365-2893.2011.01576.x

Kalantar-Zadeh, K., Kilpatrick, R. D., McAllister, C. J., Miller, L. G., Daar, E. S., Gjertson, D. W., ... \& Greenland, S. (2007). Hepatitis C virus and death risk in hemodialysis patients. Journal of the American Society of Nephrology, 18(5), 1584-1593. https://doi.org/10.1681/ASN.2006070736

Kalantar-Zadeh, K., McAllister, C. J., \& Miller, L. G. (2005). Clinical characteristics and mortality in hepatitis C-positive haemodialysis patients: a population based study. Nephrology Dialysis Transplantation, 20(8), 1662-1669. https://doi.org/10.1093/ndt/gfh895

Koziel, M. J. (1997). The role of immune responses in the pathogenesis of hepatitis C virus infection. Journal of Viral Hepatitis, 4, 31-41. https://doi.org/10.1111/j.1365-2893.1997.tb00178.x 
Mohamed, M. K., Hussein, M. H., Massoud, A. A., Rakhaa, M. M., Shoeir, S., Aoun, A. A., \& Aboul, M. N. (1996). Study of the risk factors for viral hepatitis C infection among Egyptians applying for work abroad. The Journal of the Egyptian Public Health Association, 71(1-2), 113-147.

Moradpour, D., \& Penin, F. (2013). Hepatitis C virus proteins: from structure to function. In Hepatitis C virus: from molecular virology to antiviral therapy (pp. 113-142). Springer, Berlin, Heidelberg. https://doi.org/10.1007/978-3-642-27340-7_5

Natov, S. N., \& Pereira, B. J. (2005). Hepatitis C virus in chronic dialysis patient. The Italian Journal of Urology and Nephroctomy, 57(3), 175-197.

Nelson, P. K., Mathers, B. M., Cowie, B., Hagan, H., Des Jarlais, D., Horyniak, D., \& Degenhardt, L. (2011). Global epidemiology of hepatitis B and hepatitis $\mathrm{C}$ in people who inject drugs: results of systematic reviews. The Lancet, 378(9791), 571-583. https://doi.org/10.1016/S0140-6736 (11)61097-0

Pallás, J. R., Fariñas-Álvarez, C., Prieto, D., \& Delgado-Rodríguez, M. (1999). Coinfections by HIV, hepatitis B and hepatitis $\mathrm{C}$ in imprisoned injecting drug users. European journal of epidemiology, 15(8), 699-704. https://doi.org/10.1023/A:1007619614350

Pawlotsky, J. M. (2003). Hepatitis C virus genetic variability: pathogenic and clinical implications. Clinics in liver disease, 7(1), 45-66. https://doi.org/10.1016/S1089-3261(02)00065-X

Roberts, C. L., \& Algert, C. S. (2000). The urban and rural divide for women giving birth in NSW, 1990-1997. Australian and New Zealand journal of public health, 24(3), 291-297. https://doi.org/10.1111/j.1467-842X.2000.tb01571.x

Westermann, C., Peters, C., Lisiak, B., Lamberti, M., \& Nienhaus, A. (2015). The prevalence of hepatitis C among healthcare workers: a systematic review and meta-analysis. Occup Environ Med, 72(12), 880-888. https://doi.org/10.1136/oemed-2015-102879

World Health Organization [WHO]. (2014). Obesity and overweight. Fact sheet number 311. World Health Organisation, 5-1.

Xia, X., Luo, J., Bai, J., \& Yu, R. (2008). Epidemiology of hepatitis C virus infection among injection drug users in China: systematic review and meta-analysis. Public health, 122(10), 990-1003. https://doi.org/10.1016/j.puhe.2008.01.014

Yildirim, B., Tahan, V., Ozaras, R., Aytekin, H., Mert, A., Tabak, F., \& Senturk, H. (2005). Hepatitis C virus risk factors in the Turkish community. Digestive diseases and sciences, 50(12), 2352-2355. https://doi.org/10.1007/s10620-005-3061-3

\section{Copyrights}

Copyright for this article is retained by the author(s), with first publication rights granted to the journal.

This is an open-access article distributed under the terms and conditions of the Creative Commons Attribution license (http://creativecommons.org/licenses/by/4.0/). 